\title{
Optimization of a Bitumen Binder Modification Process Under Continuous Operation Conditions
}

\author{
ELENA A. CHIGORINA, ANATOLY L. RAZINOV, \\ VICTORIA S. RYABENKO, YULIA A. UBASKINA and ALEKSANDR S. SHIKUNOV
}

Federal State Unitary Enterprise «State Scientific Research Institute of Chemical Reagents and High

Purity Chemical Substances» (FSUE «IREA»), Bogorodsky val, 3, Moscow, Russia, 107076.

${ }^{*}$ Corresponding author E-mail: echigorina@mail.ru

http://dx.doi.org/10.13005/ojc/320617

(Received: October 08, 2016; Accepted: November 15, 2016)

\begin{abstract}
This paper presents an analysis of batch and continuous modification modes of BND 60/90 bitumen binder with petroleum resin. Optimal conditions, namely modification time, stirring rate, and the ratio of components were found. The conditions of continuous operation mode were further optimized.
\end{abstract}

Keywords: Bitumen, Petroleum resin, Asphalt, Protection coating,

Organic solvent, Industrial oil, Continuous mode reactor.

\section{INTRODUCTION}

Asphalt concrete is the most practical and widespread paving material. Although it has many benefits, some drawbacks still exist: cracking upon time, pavement scaling, spalling etc. Heavy traffic, overloaded trucks and climatic factors speed up the degradation processes. Therefore, it is important to develop and implement efficient materials and technologies to protect the road pavement from workload and climatic factors in order to prolong their working lifespan.
A common method used for the prevention of asphalt concrete pavement degradation is the application of protective layers to the surface (thin layer coating of the pavement with bitumen emulsion or protective compositions) ${ }^{1}$.

Treatment with protective impregnation compositions does not require power-consuming or expensive equipment and large amounts of raw materials.

After the treatment of the surface of asphalt concrete, the impregnation composition forms a 
strong thin hydrophobic film on the whole surface of the pavement, providing high protective properties. Consumption of the material per square meter of the pavement is low.

$\ln ^{2}$ we earlier described an optimal ratio of components for a protective impregnation composition based on road bitumen of BND $60 / 90$ grade which is modified by a petroleum resin (PR). Physico-chemical, technological and working parameters of the prepared samples of the compositions were described.

All the samples of the impregnation composition were prepared in batch operation mode: the bitumen binder was modified by the introduction of PR (up to 15 mass \%) in a steel reactor with an overhead stirrer. The initial temperature was $160^{\circ} \mathrm{C}$, then it was maintained not higher than $180^{\circ} \mathrm{C}$ for 90 (industrial oil was used as a plasticized when needed). The modified binder was then combined with the solvent by pumping the latter to the reactor.

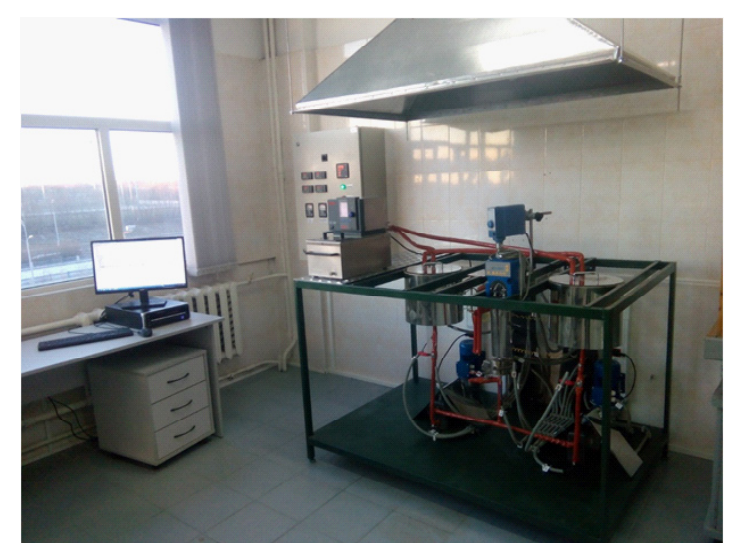

Fig. 1: Laboratory model of a flow reactor to produce a binder component
To evaluate the transfer of the technology to a pilot scale, it is important to consider the analysis of batch and continuous operation modes of binder modification, as well as to select the optimal conditions: time of modification, stirring rate, and ratio of the components.

The goal of the current research was to optimize the conditions of continuous mode modification of the bitumen binder.

\section{MATERIAL AND METHODS}

For comparison, materials from different manufacturers of BND 60/90 grade bitumen were used. The manufacturers were JSC «SlavneftYANOS» (YANOS), «Gazpromneft - Moscow oil processing plant» LLC (MNPZ) and «JSC Ufa Refinery» (UNPZ).

Viscous road bitumen of the 60/90 grade is the most demanded bitumen for the production of asphalt concrete pavement, because its rheological properties match the requirements for roadwork to the greatest extent. It is used as a binder in the construction and reconstruction of road pavements.

Petroleum resin (PR) "Sibplast" was selected as the modifying agent, while industrial oils I-20 and I-30A were used as plasticizers (Tables 2 and 3 ).

Petroleum resin as film former described $\mathrm{in}^{5-9}$, and the use of industrial oil as plasticizer in [10].

The modification process under continuous operation mode conditions was performed as follows:

Table 1: Properties of raw bitumen

\begin{tabular}{lcccccc}
\hline $\begin{array}{l}\text { Bitumen } \\
\text { BND 60/90 }\end{array}$ & $\begin{array}{c}\text { Penetration } \mathbf{0 , 1} \mathbf{~ m m} \\
\mathbf{2 5}^{\circ} \mathbf{C}\end{array}$ & $\begin{array}{c}\text { Softening } \\
\text { temperature, } \\
{ }^{\circ} \mathbf{C}\end{array}$ & $\mathbf{0}^{\circ} \mathbf{C}$ & $\begin{array}{c}\text { Ductility, sm } \\
\mathbf{2 5}^{\circ} \mathbf{C}\end{array}$ & $\begin{array}{c}\text { Fraass } \\
\text { breaking } \\
\text { point, }{ }^{\circ} \mathbf{C}\end{array}$ \\
\hline YANOS & 60 & 17,5 & 53 & 4,2 & 80 & $-14,5$ \\
MNPZ & 68,5 & 20,2 & 51 & 5 & 92 & -14 \\
UNPZ & 60 & 16,6 & 51 & 4,7 & 150 & -14 \\
\hline
\end{tabular}


The bitumen $(1000 \mathrm{~g})$ was heated to $130^{\circ} \mathrm{C}$ and placed to a steel vessel $(2000 \mathrm{~mL})$ equipped with a hot plate $\left(500^{\circ} \mathrm{C}\right.$ maximum temperature) with electric heat regulator, an overhead propeller stirrer and an electronic thermometer. The stirrer blade length was $70 \mathrm{~mm}$. The hot plate was turned on and the stirring rate set to $500 \mathrm{rpm}$. The heat regulator was set to $450^{\circ} \mathrm{C}$, when the inner temperature reached $160^{\circ} \mathrm{C}$, petroleum resin was quickly added in one portion. When the temperature reached $170^{\circ} \mathrm{C}$, the time count was started. When the inner temperature reached $175^{\circ} \mathrm{C}$, the hot plate temperature was set to $320-330^{\circ} \mathrm{C}$. The heating time of the modified bitumen was 30 minutes. The time of modification was shortened by $7.5 \mathrm{~min}$. Samples were taken after $30,45,60$, and 90 minutes of modification time.

To evaluate the continuous operation mode of modification of the bitumen binder we constructed a laboratory model of a flow reactor for the preparation of the binding component. The summary of the process is in dispensing bitumen and petroleum resin, heating the mixture up to $180^{\circ} \mathrm{C}$ and feeding it into the steady-flow reactor where the modification process occurs. The model has several entrance points for the introduction of industrial oil. Piston pumps were selected for the feeding of PR and bitumen. The technological parameters of the model can be managed either by a computer or from a control panel (Figure 1).

\section{RESULT AND DISCUSSION}

To evaluate the transition of the technology to a pilot scale, an analysis of batch and continuous operation modes of modification of the bitumen binder was performed. Laboratory (up to $10 \mathrm{~kg}$ ) and semi-industrial (up to $200 \mathrm{~kg}$ ) conditions for the preparation of the product were considered. The parameters analyzed included: loading of the raw material, efficient stirring, heat retention of the reaction mass. The analysis of the modification schemes is given in Table 4 .

Table 2: Physical and chemical properties of the PR "Sibplast"

\begin{tabular}{|c|c|c|}
\hline Properties & \multicolumn{2}{|l|}{ Index } \\
\hline External & \multicolumn{2}{|c|}{$\begin{array}{l}\text { The solid from yellow } \\
\text { to brown in pieces }\end{array}$} \\
\hline Softening temperature, ${ }^{\circ} \mathrm{C}$ & \multicolumn{2}{|c|}{$80-130$} \\
\hline Mass fraction of water, $\%$, not more & \multicolumn{2}{|l|}{0,2} \\
\hline Mass fraction of ash content, $\%$, not more & \multicolumn{2}{|l|}{0,4} \\
\hline Acid number, mg KOH / g, not more & \multicolumn{2}{|l|}{1,0} \\
\hline Mass fraction of mechanical impurities, $\%$, not more & \multicolumn{2}{|l|}{0,3} \\
\hline \multirow[t]{2}{*}{ Unit } & \multicolumn{2}{|c|}{ Norm for brend } \\
\hline & $\mathrm{I}-20 \mathrm{~A}$ & $\mathrm{I}-30 \mathrm{~A}$ \\
\hline Kinematic viscosity at $40^{\circ} \mathrm{C}, \mathrm{mm}^{2} / \mathrm{s}$ & $29-35$ & $41-51$ \\
\hline Acid number, mg KOH / g, not more & 0,03 & 0,05 \\
\hline Ash content, $\%$, not more & 0,005 & 0,005 \\
\hline Sulfur content of sulfur in petroleum oils, $\%$, not more & 1,0 & \\
\hline Content of mechanical impurities & non & \\
\hline Water content & traces & \\
\hline Density at $20^{\circ} \mathrm{C}, \mathrm{kg} / \mathrm{m}^{3}$, no more & 890 & \\
\hline Pour Point ${ }^{\circ} \mathrm{C}$, not higher & -15 & \\
\hline Flash point in open crucible, ${ }^{\circ} \mathrm{C}$, not lower & 200 & 210 \\
\hline
\end{tabular}


The most important difference of the continuous mode from the batch mode is the stable power consumption without any peak loads. The finish warming of the mixture is performed by a pipe furnace in less than $1 \mathrm{~min}$ prior to feeding into the reactor. Heating from 160 to $180^{\circ} \mathrm{C}$ in batch mode conditions should require not more than $30 \mathrm{~min}$. For the $10 \mathrm{~kg}$ and especially $200 \mathrm{~kg}$ scale it would require heating equipment of increased power capacity. Due to the high heat retention of the reaction mass, any particular reactor size requires additional selection of modification conditions.

The continuous operation mode scheme has significant drawbacks in terms of loading of the raw materials (more expensive equipment is needed). In the batch scheme, the loading is performed by manual labor or using equipment with loading rate that can be regulated in a considerably wide range. In the case of the continuous mode, special dosage units are required that provide high accuracy and stability of operation. The cost of such equipment is at least 10 times greater than the cost of equipment for the batch process. However, in this case, automated control systems can be used, which would decrease labor costs and allow to automate the production.
The main difference of the continuous operation mode from the batch one is the material flow management. While in the batch scheme the weight or volume of the loaded components are preliminary measured, in the continuous process type the component ratios are determined by the dosage units.

Several dependencies of the binder properties were found out in the study of bitumen modification with PR:

- $\quad$ From the reaction mass stirring rate;

- $\quad$ From the modification time in combination with the operation mode (batch and continuous);

- $\quad$ From the bitumen to PR ratio.

Study of the reaction mass stirring rate on the binding component properties

The modification of BND 60/90 grade bitumen was performed at 100, 200500 and 1000 rpm of the propeller stirrer.

$\begin{array}{ll}\text { - } & \text { Flow reactor temperature: } 180^{\circ} \mathrm{C} ; \\ \text { - } & \text { Stirring with a propeller stirrer; } \\ \text { - } & \text { Production capacity } 1100 \mathrm{~g} / \mathrm{h} ;\end{array}$

Table 4: Analysis of schemes modification bitumen

\begin{tabular}{|c|c|c|c|c|}
\hline \multirow[t]{3}{*}{ Unit } & \multirow{2}{*}{\multicolumn{2}{|c|}{ Scheme of periodic modification }} & \multirow{2}{*}{\multicolumn{2}{|c|}{$\begin{array}{l}\text { Scheme of continuous modification } \\
\text { per transaction }\end{array}$}} \\
\hline & & & & \\
\hline & $10 \mathrm{~kg}$ & $200 \mathrm{~kg}$ & $10 \mathrm{~kg}$ & $200 \mathrm{~kg}$ \\
\hline Bitumen loading & Manually & $\begin{array}{l}\text { Pump without } \\
\text { adjusting feed }\end{array}$ & \multicolumn{2}{|c|}{$\begin{array}{l}\text { Pump with } \\
\text { adjustable flow }\end{array}$} \\
\hline PR loading & Manually & $\begin{array}{l}\text { Manually or } \\
\text { dispenser }\end{array}$ & \multicolumn{2}{|c|}{$\begin{array}{c}\text { Dispenser or a } \\
\text { pump with adjustable } \\
\text { flow }\end{array}$} \\
\hline Industrial oil loading & \multicolumn{2}{|c|}{ Manually } & \multicolumn{2}{|c|}{$\begin{array}{l}\text { Pump with } \\
\text { adjustable flow }\end{array}$} \\
\hline Solvent loading & Manually / Pump & $\begin{array}{l}\text { Pump without } \\
\text { adjusting feed }\end{array}$ & \multirow{2}{*}{\multicolumn{2}{|c|}{$\begin{array}{l}\text { Pump with } \\
\text { adjustable flow }\end{array}$}} \\
\hline Efficient mixing & & Possibly & & \\
\hline Fast heating & Possible & $\begin{array}{l}\text { Possible with the } \\
\text { increased power } \\
\text { heaters }\end{array}$ & \multicolumn{2}{|c|}{ Possible } \\
\hline $\begin{array}{l}\text { The thermal inertia } \\
\text { of the masses to be } \\
\text { modified }\end{array}$ & Low & High & Low & High \\
\hline
\end{tabular}


- $\quad$ Sampling was carried out from a reactor valve placed on the $0.5 \mathrm{~L}$ height which corresponds to 30 min process time.

The main controlled binder parameter: penetration at $25^{\circ} \mathrm{C}$.
The data on the dependency of penetration from the stirring rate are given in Table 5.

Analysis of the results shows that the value for penetration does not change for stirring rates above $500 \mathrm{rpm}$. So we selected this stirring rate for further experiments.

Table 5: The dependence of the penetration of the binder mixing speed

\begin{tabular}{|c|c|c|c|c|}
\hline \multirow{2}{*}{$\begin{array}{l}\text { Bitumen } \\
\text { BND 60/90 }\end{array}$} & \multicolumn{4}{|c|}{ Penetration at $25^{\circ} \mathrm{C} 0,1 \mathrm{~mm}$ and stirrer speed } \\
\hline & 100 rpm & 200 rpm & 500 rpm & $1000 \mathrm{rpm}$ \\
\hline MNPZ & 45 & 38 & 37 & 37 \\
\hline UNPZ & 37 & 32 & 29 & 29 \\
\hline YANOS & 42 & 35 & 31 & 31 \\
\hline
\end{tabular}

Table 6: The dependence binder penetration at $25^{\circ} \mathrm{C}$ by modification time in a periodic and continuous modes

\begin{tabular}{|c|c|c|c|c|c|c|}
\hline \multirow[t]{2}{*}{$\begin{array}{l}\text { Bitumen } \\
\text { BND 60/90 }\end{array}$} & \multirow[t]{2}{*}{$\begin{array}{l}\text { Penetration at } \\
25^{\circ} \mathrm{C} 0,1 \mathrm{~mm}\end{array}$} & \multicolumn{5}{|c|}{$\begin{array}{c}\text { Penetration at } 25^{\circ} \mathrm{C} 0,1 \mathrm{~mm} \text { during } \\
\text { the modification, } \mathrm{min}\end{array}$} \\
\hline & & 0 & 30 & 45 & 60 & 90 \\
\hline \multicolumn{7}{|c|}{ Periodic modification } \\
\hline YANOS & 75 & 63 & 55 & 53 & 52 & 50 \\
\hline UNPZ & 60 & 48 & 44 & 42 & 40 & 39 \\
\hline MNPZ & 60 & 48 & 41 & 37 & 34 & 32 \\
\hline \multicolumn{7}{|c|}{ Continuous modification } \\
\hline YANOS & 75 & 63 & 31 & 30 & 30 & 29 \\
\hline UNPZ & 60 & 48 & 29 & 29 & 28 & 28 \\
\hline MNPZ & 60 & 48 & 37 & 37 & 36 & 36 \\
\hline
\end{tabular}

Table 7: The dependence binder softening temperature at $25^{\circ} \mathrm{C}$ by periodic and continuous modes

\begin{tabular}{|c|c|c|c|c|c|}
\hline \multirow[t]{2}{*}{$\begin{array}{l}\text { Bitumen } \\
\text { BND 60/90 }\end{array}$} & \multirow[t]{2}{*}{$\begin{array}{l}\text { Softening } \\
\text { temperature, }{ }^{\circ} \mathbf{C}\end{array}$} & \multicolumn{4}{|c|}{$\begin{array}{l}\text { Softening temperature, }{ }^{\circ} \mathrm{C} \text { during } \\
\text { the modification, } \min \end{array}$} \\
\hline & & 30 & 45 & 60 & 90 \\
\hline \multicolumn{6}{|c|}{ Periodic modification } \\
\hline YANOS & 53 & 53 & 54 & 54 & 54 \\
\hline UNPZ & 51 & 52 & 52 & 53 & 53 \\
\hline MNPZ & 51 & 53 & 53 & 53 & 54 \\
\hline \multicolumn{6}{|c|}{ Continuous modification } \\
\hline YANOS & 53 & 54 & 54 & 54 & 55 \\
\hline UNPZ & 51 & 52 & 52 & 53 & 53 \\
\hline MNPZ & 51 & 52 & 52 & 53 & 53 \\
\hline
\end{tabular}


Study of the dependency of the binder properties from the modification time and comparison of results for batch and continuous operation modes

\section{Process conditions}

- $\quad$ Flow reactor temperature: $180^{\circ} \mathrm{C}$;

- $\quad$ Stirring with a propeller stirrer at $500 \mathrm{rpm}$;

- Production capacity $1000 \mathrm{~g} / \mathrm{h}$ and $670 \mathrm{~g} / \mathrm{h}$;
- $\quad$ Sampling was carried out from reactor valves placed on the $0.5 \mathrm{~L}$ and $1 \mathrm{~L}$ height which corresponds to $30 \mathrm{~min}$ and $60 \mathrm{~min}$ process time for the $1000 \mathrm{~g} / \mathrm{h}$ production capacity, or 45 and $90 \mathrm{~min}$ for $670 \mathrm{~g} / \mathrm{h}$ capacity.

The following properties of the binder were compared: penetration at $25^{\circ} \mathrm{C}$, ball-and-ring softening temperature, Fraas brittle point.

Table 8: The dependence Fraass breaking point temperature by modification time in a periodic and continuous modes

\begin{tabular}{|c|c|c|c|c|c|}
\hline \multirow[t]{2}{*}{$\begin{array}{l}\text { Bitumen } \\
\text { BND 60/90 }\end{array}$} & \multirow[t]{2}{*}{$\begin{array}{l}\text { Fraass breaking } \\
\text { point, }{ }^{\circ} \mathrm{C}\end{array}$} & \multicolumn{4}{|c|}{$\begin{array}{l}\text { Fraass breaking point, } \\
{ }^{\circ} \mathrm{C} \text { during the modification, min }\end{array}$} \\
\hline & & 30 & 45 & 60 & 90 \\
\hline \multicolumn{6}{|c|}{ Periodic modification } \\
\hline YANOS & $-14,5$ & -9 & -10 & -10 & -9 \\
\hline UNPZ & -14 & $-5,5$ & -6 & $-6,5$ & -6 \\
\hline MNPZ & -14 & -10 & -10 & -10 & -10 \\
\hline \multicolumn{6}{|c|}{ Continuous modification } \\
\hline YANOS & $-14,5$ & -1 & -1 & 0 & 0 \\
\hline UNPZ & -14 & $-1,5$ & -1 & 0 & 1 \\
\hline MNPZ & -14 & -9 & -9 & -9 & -8 \\
\hline
\end{tabular}

Table 9: Penetration at $25^{\circ} \mathrm{C}, 0,1 \mathrm{~mm}$ with a ratio of bitumen: PR in a continuous mode

\begin{tabular}{|c|c|c|c|c|}
\hline \multirow[t]{2}{*}{$\begin{array}{l}\text { Bitumen } \\
\text { BND 60/90 }\end{array}$} & \multirow[t]{2}{*}{$\begin{array}{l}\text { Penetration } \\
\text { at } 25^{\circ} \mathrm{C} 0,1 \mathrm{~mm}\end{array}$} & \multicolumn{3}{|c|}{$\begin{array}{l}\text { Penetration at } 25^{\circ} \mathrm{C}, 0.1 \mathrm{~mm} \\
\text { with a ratio of bitumen: } \mathrm{PR}\end{array}$} \\
\hline & & $90: 10$ & $85: 15$ & $80: 20$ \\
\hline YANOS & 75 & 43 & 31 & 25 \\
\hline UNPZ & 60 & 32 & 28 & 23 \\
\hline MNPZ & 60 & 42 & 38 & 27 \\
\hline
\end{tabular}

Table 10: Fraass breaking point ${ }^{\circ} \mathrm{C}$ with a ratio of bitumen: PR in a continuous mode

\begin{tabular}{lcccc}
\hline Bitumen & Fraass breaking & \multicolumn{3}{c}{ Fraass breaking point ${ }^{\circ} \mathbf{C}$} \\
BND 60/90 & point, ${ }^{\circ} \mathbf{C}$ & \multicolumn{2}{c}{ with a ratio of bitumen: PR } \\
& & $90: 10$ & $\mathbf{8 5 : 1 5}$ & $\mathbf{8 0 : 2 0}$ \\
\hline YANOS & $-14,5$ & -8 & $-1,5$ & 1 \\
UNPZ & -14 & -7 & -1 & 2 \\
MNPZ & -14 & -11 & -10 & -2 \\
\hline
\end{tabular}


Experimental results are given in Tables 6-8.

Analysis of the data shows that for both the batch and the continuous operation modes the maximal decline of penetration values occurs during the first 30 minutes of modification. The most important difference is in the rate at which penetration values continue to decline after this time. While for the batch operation mode it is considerable $-5-10$ units in the time range of 30-90 $\mathrm{min}$, for the continuous mode it is only 1-2 units.

The presented data demonstrate that the properties of the product are almost identical for both modification modes.

However, Fraas brittle point values are significantly higher for the continuous mode compared to the batch mode. An exception are the results for MNPZ bitumen that has a difference of 1-2 degrees in this parameter.
Study of the bitumen to PR rate on the properties of the binder product

The bitumen - PR ratio is one of the most important parameters for the development of a continuous operation mode bitumen modification process.

While in the batch mode this ratio is easily controlled, in the continuous operation it is much more difficult to set the proper material flows. Of particular importance is to set acceptable limits for the ratio, as the dosage pumps have their own tolerable deviations. It is necessary for the bitumen to $\mathrm{PR}$ ratio to be within the set interval of deviation.

\section{Process conditions}

- $\quad$ Flow reactor temperature: $180^{\circ} \mathrm{C}$;

- $\quad$ Stirring with a propeller stirrer;

- $\quad$ Production capacity $1000 \mathrm{~g} / \mathrm{h}$;

- $\quad$ Sampling was carried out from a reactor valve placed on the $0.5 \mathrm{~L}$ height which corresponds to $30 \mathrm{~min}$ process time at $1000 \mathrm{~g} / \mathrm{L}$ production capacity.

Table 11: Penetration and Fraass breaking point temperature by adding industrial oil to binder obtained continuously modified bitumen

\begin{tabular}{|c|c|c|c|c|c|}
\hline \multirow[t]{2}{*}{$\begin{array}{l}\text { Bitumen } \\
\text { BND 60/90 }\end{array}$} & \multirow[t]{2}{*}{$\begin{array}{l}\text { Industrial } \\
\text { oil, } \%\end{array}$} & \multicolumn{2}{|c|}{$\begin{array}{l}\text { Penetration at } 25^{\circ} \mathrm{C}, 0.1 \mathrm{~mm} \\
\text { with a ratio of bitumen: PR }\end{array}$} & \multicolumn{2}{|c|}{$\begin{array}{l}\text { Fraass breaking point }{ }^{\circ} \mathrm{C} \\
\text { with a ratio of bitumen: PR }\end{array}$} \\
\hline & & $90: 10$ & $85: 15$ & $90: 10$ & $85: 15$ \\
\hline YANOS & $2 \% \mathrm{I}-20 \mathrm{~A}$ & 50 & 40 & -13 & -8 \\
\hline YANOS & $3 \% \mathrm{I}-20 \mathrm{~A}$ & 54 & 46 & -16 & -11 \\
\hline YANOS & $5 \%$ I-20A & 62 & 61 & -19 & -15 \\
\hline YANOS & $2 \% \mathrm{I}-30 \mathrm{~A}$ & 48 & 39 & -9 & -4 \\
\hline YANOS & $3 \% \mathrm{I}-30 \mathrm{~A}$ & 52 & 43 & -13 & -7 \\
\hline YANOS & $5 \%$ I-30A & 57 & 49 & -15 & -10 \\
\hline UNPZ & $2 \% \mathrm{I}-20 \mathrm{~A}$ & 41 & 39 & -13 & -6 \\
\hline UNPZ & $3 \% \mathrm{I}-20 \mathrm{~A}$ & 47 & 44 & -16 & -11 \\
\hline UNPZ & $5 \% \mathrm{I}-20 \mathrm{~A}$ & 59 & 56 & -18 & -14 \\
\hline UNPZ & $2 \% \mathrm{I}-30 \mathrm{~A}$ & 37 & 35 & -9 & -3 \\
\hline UNPZ & $3 \% \mathrm{I}-30 \mathrm{~A}$ & 48 & 45 & -13 & -7 \\
\hline UNPZ & $5 \%$ I-30A & 55 & 52 & -15 & -10 \\
\hline MNPZ & $2 \% \mathrm{I}-20 \mathrm{~A}$ & 51 & 49 & -16 & -15 \\
\hline MNPZ & $3 \% \mathrm{I}-20 \mathrm{~A}$ & 56 & 55 & -18 & -18 \\
\hline MNPZ & $5 \%$ I-20A & 64 & 62 & -19 & -19 \\
\hline MNPZ & $2 \% \mathrm{I}-30 \mathrm{~A}$ & 48 & 46 & -14 & -12 \\
\hline MNPZ & $3 \% \mathrm{I}-30 \mathrm{~A}$ & 53 & 49 & -16 & -15 \\
\hline MNPZ & $5 \% \mathrm{l}-30 \mathrm{~A}$ & 61 & 59 & -18 & -17 \\
\hline
\end{tabular}


The bitumen to PR rate was: $90: 10$, $85: 15,80: 20$.

The controlled parameters were: penetration at $25^{\circ} \mathrm{C}$ and Fraas brittle point.

The experimental data are given in Tables 9 and 10.

It is clear that the bitumen to PR ratios of $90: 10$ for the continuous process and $85: 15$ for the batch process give very close results.

Preparation of the binder in continuous mode using mineral oil as an additive

\section{Process conditions}

- $\quad$ Flow reaction temperature $180^{\circ} \mathrm{C}$;

- $\quad$ Stirring with a propeller stirrer;

- $\quad$ Production capacity $1000 \mathrm{~g} / \mathrm{h}$;

- $\quad$ Sampling was carried out from a reactor valve placed on the $0.5 \mathrm{~L}$ height which corresponds to $30 \mathrm{~min}$ process at $1000 \mathrm{~g} / \mathrm{h}$ capacity.

The bitumen to PR ratio was: $90: 10$ and $85: 15$.

The controlled parameters were penetration at $25^{\circ} \mathrm{C}$ and Fraas brittle point.

The oil was fed by a peristaltic pump at the $0.5 \mathrm{~L}$ valve level through an entrance point for the oil.

The results are presented in Table 11.

\section{CONCLUSIONS}

An analysis of the batch and continuous technological schemes of a bitumen binder modification was performed.

The minimal reaction mass stirring rate to provide the perfect-mixing reactor under continuous operation was found out - 500 rpm.

The maximal decline of penetration values occurs during the first $30 \mathrm{~min}$ for both operation modes.

The most important difference of the continuous mode from the batch one is the very slow rate of penetration decline after $30 \mathrm{~min}$ process time.

The Fraas brittle point in continuous mode is significantly higher compared to the batch mode.

Modification of bitumen with bitumen to PR ratios $90: 10$ and $85: 15$ (for the continuous and batch modes, correspondingly), give very close results.

\section{ACKNOWLEDGMENT}

Applied researches are conducted with financial support of the state represented by the Ministry of Education and Science of Russia in under the Subsidy Grant Agreement No 14.579.21.0025 of June 5, 2014. (Unique Identifier for Applied Scientific Researches (project) RFMEFI57914X0025).

\section{REFERENCES}

1. Chigorina E. A., Razinov A. L., Retivov V. M. Biosci., Biotech. Res. Asia. 2014, 11(3), 1679-1683.

2. Merentcova G.S. Polzunovskiy vestnik. 2014, 1, 100-103.

3. Ubas'kina Y. A., Chigorina E.A., Razinov A. L., Ryabenko V. S., Kovtun I. D. Orient. J. Chem. 2016, 32(1), 305-311.

4. Usmanov T.K., Abdullin A.I., Emelyanicheva
E.A., Markov C.Yu. Vestnik Kazanskogo tekhnologicheskogo universiteta. 2013, 2 (16), 117-121.

5. Dumskiy Yu.V., Cherednikova G.F., Dumskiy S.Yu. Izvestia VSTU 2010, 7 (2), 127-130.

6. Fiterer E.P. Russian Coatings Journal. 2011, 1-2, 84-89.

7. Kobayashi S., Müllen K. Encyclopedia of Polymeric Nanomaterials. Springer (2015), 
1546-1550.

8. Lesnyak V.P., Gaponik L.V., Shiman D. I., Kostuk S.V., Kaputckiy F.N. Sintez, modifikaciya i primenenie neftepolimernikh smol na osnove monomersoderjashikh piroliznikh frakciy Minsk 2008, 204-245.

9. Dumskiy Yu.V., Cherednikova G.F., Dumskiy
S.Yu. , Kostorubina E.V., Kuznetcova N.A. Izvestia VSTU. 2013, 1-104 (6), 72-74.

10. Egorushkin A.V., Egorushkin V.O., Endjievskaya I.G., Vasilovskaya N.G. Modern problems of science and education 2014, 6, 265-269. 